В. А. Мєсоєдова

ДВНЗ “Івано-Франківський національний медичний університет”

\title{
СТУДЕНТСЬКИЙ НАУКОВИЙ ГУРТОК НА КАФЕДРІ КЛІНІЧНОЇ АНАТОМІЇ ТА ОПЕРАТИВНОЇ ХІРУРГІЇ ЯК ШЛЯХ ДО ВДОСКОНАЛЕННЯ ПРОФЕСІЙНИХ НАВИКІВ МАЙБУТНЬОГО ЛІКАРЯ
}

\author{
Ivano-Frankivsk National Medical University
STUDENTS' SCIENTIFIC CIRCLE AT THE CLINICAL ANATOMY AND OPERATIVE SURGERY DEPARTMENT AS THE WAY TO IMPROVE PROFESSIONAL EDUCATION OF THE FUTURE DOCTOR

\begin{abstract}
Мета роботи - охарактеризувати вагому частку студентського наукового гуртка (СНГ) у навчальному процесі студентів вищих медичних навчальних закладів та оцінити важливість роботи наукового гуртка з метою формування кваліфікованих наукових та практичних кадрів, які б працювали на благо пацієнта та нашої держави.

Основна частина. У статті розглянуто основні аспекти організації та діяльності СНГ на кафедрі клінічної анатомії та оперативної хірургії. Цілеспрямоване залучення студентів до поглибленого вивчення теоретичного матеріалу, відпрацювання практичних навичок, а також їх активної участі в науково-дослідній роботі, сприяє формуванню особистості як фахівця та науковця і мотивує до відповідальності щодо вибраної сфери діяльності. Метою СНГ є виявлення найбільш здібних і талановитих студентів, їх активна участь у наукових проблематичних дослідженнях кафедри, забезпечення формування теоретичного, клінічного та аналітичного мислення, підвищення ефективності навчального процесу й запрошення обдарованих студентів до подальшої післядипломної співпраці. Членом СНГ може стати будь-який студент, загальне керівництво веде завідувач кафедри, поточну роботу здійснює науковий керівник гуртка. Заняття проходить у декілька етапів: початковий - у вигляді міні-лекції викладач знайомить гуртківців з обраною темою, наступним етапом є зачитування студентами самостійно опрацьованої тематичної роботи, заключним етапом є жвава дискусія щодо почутого. Важливою складовою СНГ є робота в операційних кафедри, на експериментальних тваринах чи трупному матеріалі. Науково-дослідна робота гуртківців є різнонаправлена: вивчається зміна мікроциркуляторного русла, стан нервового та ендокринного апаратів тонкої кишки тощо.

Висновки. СНГ є необхідною ланкою для становлення і розвитку майбутнього фахівця. Студенти-гуртківці краще оволодівають теоретичними знаннями та практичними навичками порівняно з тими студентами, які не відвідували гурток і не брали участі у науковій роботі.
\end{abstract}

Ключові слова: студентський науковий гурток; науково-дослідна робота; оперативна хірургія; студенти.

The aim of the work - to characterize a significant share of the SSC in the educational process of students of higher medical education institutions and to assess the importance of the work of the scientific circle in order to form qualified scientific and practical staff who would work for the benefit of the patient and our state.

The main body. The article deals with the main aspects of the organization and activities of the students' scientific circle at the Department of Clinical Anatomy and Operative Surgery. Purposeful involvement of students in an in-depth study of theoretical material, developing practical skills, as well as their active participation in research work, promotes the formation of the individual as a specialist and scientist and motivates the responsibility for the chosen field of activity. The main purpose of the students' scientific circle is to identify the most capable and talented students, their active participation in scientific problematic studies of the department, providing the formation of theoretical, clinical and analytical thinking, increasing the efficiency of the educational process and inviting gifted students for further postgraduate cooperation. Any student may become a member of the students' scientific circle, the head of the department manages general guidance, and current work is carried out by the scientific adviser of the circle. The lesson consists of several stages: the initial one - in the form of a mini-lecture when a teacher introduces the chosen theme, the next step is reading out by students the self-developed thematic work, the final stage is an active discussion. An important component of the students' scientific circle is the work in the operating-rooms of the department, practice with experimental animals or corpses. The research work of participants is multi-directional: the changes of the microcirculatory channel, the state of the nervous and endocrine apparatus of the small intestine are being studied etc.

Conclusions. Students' scientific circle is a necessary link for the formation and development of a future specialist. Students-members of the students' scientific circle are better at mastering theoretical knowledge and practical skills, compared to those students who did not attend the students' scientific circle and did not participate in scientific work.

Key words: student's scientific circle; scientific research work; operative surgery; students.

(c) В. А. Мєсоєдова 
Вступ. Сучасний стан науки, сучасний темп розвитку інноваційних технологій примушують постійно оновлювати свої знання не тільки професорів та доцентів, а й студентів. Тому існує об’єктивна необхідність застосування додаткових занять, впровадження нових, цікавих методик, які наближують студента до більш реальної професійної діяльності та допомагатимуть йому сформувати і розвивати професійно-творче мислення. Одним із головних напрямів формування якісного рівня освіти є залучення студентів до науково-дослідної роботи. Науково-дослідна робота - це комплекс заходів наукового, методичного, організаційного характеру, що забезпечує навчання студентів навичок наукових досліджень відповідно до обраної спеціальності. Першою та традиційною формою організації наукової студентської роботи є студентські наукові гуртки [2, 5]. У системі підготовки майбутнього лікаря, особливо хірургічного профілю, оперативній хірургії відводиться надзвичайно важливе місце, оскільки дисципліна є містком, що поєднує теоретичну (загальнобіологічну й анатомічну) підготовку студента та практичне (клінічне) застосування набутих знань [1, 3]. Тому студентський науковий гурток (СНГ) на кафедрі клінічної анатомії та оперативної хірургії посідає вагоме місце у навчальній роботі ДВНЗ “Івано-Франківський національний медичний університет”.

Мета роботи - охарактеризувати вагому частку СНГ у навчальному процесі студентів вищих медичних навчальних закладів й оцінити важливість роботи наукового гуртка з метою формування кваліфікованих наукових та практичних кадрів, які б працювали на благо пацієнта і нашої держави.

Основна частина. Студентський науковий гурток при кафедрі являє собою невеликий колектив, який об’єднаний розробкою певної наукової проблеми відповідно до затверджених тематичних планів роботи кафедри. Науковий гурток згуртовує студентівентузіастів, діяльність яких спрямована на вдосконалення вивченого теоретичного матеріалу, набуття нових знань і практичних навичок, а також вивчення принципів та методів ведення наукової роботи; пояснення процесів і явищ, встановлення взаємозв'язків та відношень, експериментальне й теоретичне обгрунтування виявлених фактів та закономірностей [4]. Кожний студент у гуртку виконує самостійне завдання наукового керівника, яке полягає, насамперед, у самостійному творчому дослідженні.

Метою роботи студентського наукового гуртка на кафедрі клінічної анатомії та оперативної хірургії є:
- вдосконалити застосування основних практичних навичок у військово-польовій та судинній хірургії, гастрохірургії, нейрохірургії, в хірургічній та терапевтичній стоматології, в акушерстві та гінекології, з метою формування вмінь використовувати дані знання в процесі подальшого навчання та в професійній діяльності;

- сприяння в підвищенні рівня наукової підготовки студентів;

- формування в студентів наукового та клінічного мислення, що є важливим для розуміння складних фізіологічних процесів на різних рівнях організації людського організму;

- розвиток творчого мислення, розкриття інтелектуального потенціалу, підвищення самоорганізованості, свідомого ставлення до навчання, поглиблення й закріплення отриманих у процесі навчання знань.

Основними завданнями студентського наукового гуртка $\epsilon$ :

- поглиблено вивчати зі студентами дану дисципліну та формувати професійні вміння для надання медичної допомоги при різних патологічних станах та в період догляду за хворими;

- формувати вміння самостійно вирішувати клінічні ситуації, встановлювати діагнози, правильно, з розумінням, трактувати лабораторні та інструментальні методи дослідження, а також вміло виконувати поставлені завдання й злагоджено працювати у колективі;

- організувати науково-дослідну роботу зі студентами та прищепити до неї інтерес;

- залучити студентів до експериментальних досліджень;

- забезпечити активну участь студентів у проведенні наукових конференцій, наукових семінарів та конкурсів на кращу наукову роботу.

Членом СНГ може стати будь-який студент, який успішно освоює навчальну програму (не має незадовільних оцінок за підсумками навчального семестру) і має бажання брати участь у науково-дослідній роботі кафедри. Прийом здійснюється в добровільному порядку на підставі усної заяви студента.

Загальне керівництво над роботою СНГ веде завідувач кафедри, поточну роботу здійснює науковий керівник гуртка. Засідання СНГ відбувається тричі на місяць, тему заняття вибирає куратор, це дає змогу студентам отримати та вивчити надсучасну наукову та практичну інформацію. До початку навчального семестру складається календарнотематичний план роботи студентського науково- 
го гуртка 3 дисципліни “Оперативна хірургія та топографічна анатомія”, з зазначенням теми та куратора засідання, кожне наступне заняття проводить інший викладач кафедри. Робота студентів може бути організована по-різному: семінар, наукові дебати, практикум та індивідуальна робота. Студенти вивчають техніку хірургічних маніпуляцій, виконують дослідницьку роботу, а також переглядають фільми про виконання різних операцій, які не демонструвалися на лекціях. Матеріали заняття розробляє науковий керівник СНГ, опираючись на взаємозв’язок між теорією та практикою. На початку заняття викладач знайомить гуртківців з обраною темою у вигляді міні-лекції, оголошує мету та план засідання. Наступним етапом є залучення студентів: у вигляді рефератів та доповідей вони діляться здобутою інформацією (згідно з календарно-тематичним планом; завдання вони отримують напередодні) про найновітніші винаходи чи появу нових діагностичних або лікувальних методик. Готуючись самостійно, студенти-гуртківці вчаться та виховують у собі відповідальність, вміння якісно та доступно подати матеріал, відстоювати свою думку, позицію. Заключним етапом кожного засідання наукового гуртка є жвава дискусія, “здорова” дискусія.

Важливою складовою є робота студентів в операційних кафедри, на експериментальних тваринах чи трупному матеріалі. Майбутні лікарі відпрацьовують навички простих та більш складних оперативних втручань, зокрема: “Первинна хірургічна обробка ран”, “Перев’язка судин на протязі”, “Трахеостомія”, “Апендектомія”, “Резекція кишки 3 формуванням кишкових анастомозів”, “Ревізія органів черевної порожнини”, “Пластика коронарних судин”. Крім оволодіння суто хірургічною технікою, студенти досконало засвоюють методи підготовки до операції: обкладання операційного поля стерильною білизною, поля інструментального столика операційної сестри та їх призначення, позиції утримання хірургічних інструментів, техніку місцевої анестезії. Близько 85 \% колишніх гуртківців після закінчення університету працюють лікарями хірургічного профілю.

\section{Список літератури}

1. Науковий студентський гурток на кафедрі хірургії як форма наукової діяльності студентів / С. М. Василюк, А. Г. Шевчук, В. М. Федорченко [та ін.] // Шпитальна хірургія. - 2014. - № 3. - С. 94-96.

2. Студентський науковий гурток як допоміжна форма теоретичного та практичного навчання за кредит-
Науково-дослідна робота студентів присвячена застосуванню різних медичних клеїв, розробці єюнопластики, вивченню мікроциркуляторного русла тонкої кишки при експериментальній непрохідності, зміні електролітного обміну після правобічної геміколектомії, стану нервового та ендокринного апаратів тонкої кишки, інсулярного апарату підшлункової залози, а також сім'яників після часткової резекції тонкої кишки. Результати проведених наукових досліджень представлені на звітних студентських наукових конференціях.

Студентський науковий гурток діє з періоду заснування кафедри і користується великою популярністю серед студентів. В різні роки гуртком керували: асистент С. I. Федусів, доцент К. О. Діамантопуло, асистент В. В. Регуш, доцент I. В. Котурбаш, професор Ю. Л. Попович, доцент С. В. Купчак, асистент О. В. Лазуркевич, доцент В. М. Федорак, доцент В. О. Кавин. Кожного року в гуртку працювало від 10 до 30 студентів IIIII курсів, а інколи IV, V і VI курсів. Всього за період існування гуртка в ньому займалося близько 1000 студентів.

Висновки. 1. Студентський науковий гурток $€$ необхідною ланкою для становлення і розвитку майбутнього фахівця, лікаря-професіонала. Цілеспрямовано займаючись у науковому гуртку, студенти отримують можливість суттєво підвищити свою професійну майстерність, рівень теоретичної та науково-практичної підготовки. Участь у роботі предметного гуртка сприяє підвищенню якості навчання, закріпленню, розширенню і вдосконаленню набутих знань та навиків.

2. Робота в студентському науковому гуртку оптимізує процес навчання студентів, мотивує до більш поглибленого вивчення вибраної діяльності та сприяє проведенню дослідницької роботи протягом всього професійного життя.

3. Багаторічний досвід свідчить, що студентигуртківці краще оволодівають теоретичними знаннями та практичними навичками, ніж ті, що не беруть участі у науковій роботі.

но-модульною системою освіти / Л. О. Волошина, О. Ю. Оліник, Л. Д. Кушнір [та ін.] // Актуальні питання вищої медичної та фармацевтичної освіти: досвід, проблеми, інновації та сучасні технології : матеріали навч.-метод. конф., Чернівці, 18 квітня 2012 р. - Чернівці, 2012. - С. 24. 
3. Волощук Н. І. Індивідуальна робота в студентському науковому гуртку кафедри фармакології як фактор формування професійних компетенцій / Н. I. Волощук, О. М. Денисюк // Буковинський медичний вісник. - 2014. Т. 18, № 4 (72). - С. 257-259.

4. Геруш I. В. Роль науково-дослідницької роботи студентів медичних ВН3 III-IV рівнів акредитації в їх становленні як майбутніх фахівців / I. В. Геруш, I. М. Яремій, О. Ю. Кушнір // Досягнення і перспективи впровадження кредитно-модульної системи організації навчального процесу у вищих медичних (фармацевтичному) навчальних закладах України” : матеріали Всеукр. навч.-наук. конф. $з$ міжнар. участю, присвяченої 160-річчю 3 дня народження І. Я. Горбачевського, Тернопіль, 15-16 травня, 2014 р. - Тернопіль, 2014. - С. 186-188.

5. Жураківська О. Я. Навчально-дослідна робота студентів як засіб підвищення ефективності навчального процесу у вищих медичних закладах України / О. Я. Жураківська // Галицький лікарський вісник. 2015. - T. 22, № 1. - С. 106-107.

\section{References}

1. Vasyliuk, S.M., Shevchuk, A.H, Fedorchenko, V.M., Bitska, I.V., \& Hudyvok, V.I. (2014). Naukovyi studentskyi hurtok na kafedri hirurhii yak forma naukovoi diialnosti studentiv [Scientific student group at the department of surgery as a form of scientific activity of students]. Shpytalna khirurhiia - Hospital Surgery, 3, 94-96 [in Ukrainian].

2. Voloshyna, L.O., Olinyk, O.Yu., \& Kushnir, L.D. (2012). Studentskyi naukovyi hurtok - yak dopomizhna forma teoretychnoho ta praktychnoho navchannia za kredytno-modulnoiu systemoiu osvity [Students'scientific circle as an auxiliary form of theoretical and practical training in the credit-transfer system of education]. Navch.metod. konf "Aktualni pytannia vyshchoi medychnoi ta farmatsevtychnoi osvity: dosvid, problemy, innovatsii ta suchasni tekhnolohii" - Education-methodical conference "Topical Issues in Higher Medical and Pharmaceutical Education: experience, problems, innovation and contemporary technologies". Chernivtsi [in Ukrainian].

3. Voloshchuk, N.I., \& Denysiuk, O.M. (2014). Indyvidualna robota $\mathrm{v}$ studentskomu naukovomu hurtku kafedry farmakolohii yak faktor formuvannia profesiinykh kompetentsii [Individual work at the students' scientific circle of pharmacology department as a factor for professional competence formation]. Bukovynskyi medychnyi visnyk Bukovynian Medical Journal, 4, 257-259 [in Ukrainian].

4. Herush, I.V., Yaremii, I.M., \& Kushnir, O.Yu. (2014). Rol naukovo-doslidnytskoi roboty studentiv medychnykh VNZ III-IV rivniv akredytatsii v yikh stanovlenni yak maibutnikh fakhivtsiv [The role of research work of students of medical higher educational institutions of III-IV levels of accreditation in their formation as future specialists]. Materialy Vseukrainskoi navchalno-naukovoi konferentsii z mizhnarodnoiu uchastiu "Dosiahnennia $i$ perspektyvy vprovadzhennia kredytno-modulnoi systemy orhanizatsii navchalnoho protsesu u vyshchykh medychnykh (farmatsevtychnomu) navchalnykh zakladakh Ukrainy”Materials of the All-Ukrainian Educational and Scientific Conference with International Participation "Achievements and Perspectives of the credit-transfer system of the organization of the educational process in the Higher Medical (Pharmaceutical) institutions of Ukraine” (pp. 186-188). Ternopil [in Ukrainian].

5. Zhurakivska, O.Ya. (2015). Navchalno-doslidna robota studentiv yak zasib pidvyshchennia efektyvnosti navchalnoho protsesu u vyshchykh medychnykh zakladakh Ukrainy [Educational and research work of students as a means of increasing the effectiveness of learning process in higher medical institutions of Ukraine]. Halytskyi likarskyi visnyk - Galician Medicinal Journal, 1, 106-107 [in Ukrainian]. 